


\title{
SANTA CATARINA: TRAGÉDIA OU DESCASO?
}

\author{
SANTA CATARINA: TRAGEDY OR DISREGARD?
}

\author{
Luciana Maria Lopes - UFG \\ luc-lopes@uol.com.br
}

Escrevo movida por revolta pelo ocorrido em Santa Catarina, e também pelas tragédias do passado que sempre, no presente, se renovam, desencadeadas pela omissão de autoridades e instituições que, nunca, e por nada, são responsabilizadas. Do outro lado está o povo, eternamente passivo porque ausente de cidadania. Cansam os persistentes vícios de uma sociedade mal gerenciada e sempre anistiada pelo corporativismo e maniqueísmos da nossa república das bananas gestada nos intestinos de uma colonização perversa da qual herdamos o compadrio, o toma lá-dá-cá, a corrupção, a esperteza, a irresponsabilidade e o verniz de modernidade sob o qual escondemos milenar e persistente atraso. Provas deste se encontram, por exemplo, na falta de planejamento de uso do solo urbano e no controle da especulação imobiliária.

Alguém já pensou em tirar do hino nacional o trecho "deitado eternamente em berço esplêndido" que só vale para os que, vergonhosamente, sugam o sangue (o dinheiro) do povo cansado de maus exemplos (de governantes, instituições e especuladores imobiliários), povo que trabalha, anda de ônibus, não tem saúde, nem educação, nem infra-estrutura e que vê, Brasil afora, suas casas rolarem encosta abaixo e serem inundadas pelas águas dos rios cheios do esgoto proveniente da falta de políticas públicas e de administração voltada para os reais interesses da população. De onde vem a violência? Da falta de oportunidades, da falta de decência por parte dos que são eleitos e pagos, supostamente, para zelar por condições de vida minimamente dignas para o povo brasileiro alvo de altíssima carga de impostos logo tragados pela rede da corrupção.

Mas voltemos às ditas tragédias que de naturais nada têm. A maioria delas são previsíveis, possíveis de serem evitadas.

Comecemos pelo significado da palavra "encostas". As encostas dos morros são também chamadas de vertentes pois vertem água para baixo porque, até onde se saiba (sabe lá o que anda sendo gestado nos bastidores das câmaras, congresso e senado), nenhuma medida provisória tentou revogar a lei da gravidade que faz com que as águas corram para baixo. Morro acima, 
pelo que até agora se sabe no Brasil, deve ir o rio São Francisco que terá seu curso desviado e, valha-nos Deus, subirá serra pedregosa cheia de mandacarus, xiquexiques e de solos e povos sofridos, ressequidos e sedentos de água e de políticos que com eles se importem. Maior do que o desvio do leito do São Francisco teme-se vá ser o desvio dos recursos públicos uma vez que nós, cidadãos brasileiros, nascemos para pagar impostos que, justa e decentemente, deveriam retornar em serviços essenciais: saúde, educação e infraestrutura de modo a livrar a população de previsíveis "infortúnios".

Examinemos o caso de Santa Catarina. O relevo da região, assim como aquele do sudeste brasileiro, é caracterizado pela presença de serras e/ou de morrarias com vales para os quais vertem as águas das áreas mais altas do entorno. Adicione-se a tal fato a existência, no geral, de solos muito profundos, espessos, que se tornam muito perigosos quando saturados pela água das insistentes chuvas que neles teimam em se infiltrar, desestabilizandoos e causando deslizamentos de terra. Em setores que recebem o sugestivo nome de "áreas de risco à ocupação" (encostas instáveis de morros) foram edificadas casas e prédios. A legislação que regula o uso do solo urbano existe para impedir que tais áreas de risco sejam ocupadas. Por que não foi utilizada para prevenção de anunciado desastre?

Agora vamos para os vales que são definidos como locais mais baixos para onde se destinam tanto as águas do lençol freático quanto as águas superficiais. No fundo do vales o lençol freático aflora para formar os rios. Estes tem seus ciclos regulados pelos períodos de cheia e vazante, e pelos espaços representados pelas planícies de inundação. Este termo encerra em si sua função: abrigar as águas do rio quando do seu natural extravasamento nas épocas de cheia. Há legislação que regula a ocupação das áreas das planícies sujeitas à inundação. Porém, aquelas do vale do Itajaí foram ocupadas. Por que não foi feito, antecipadamente, o planejamento de uso do solo com a finalidade da prevenção de previsível desastre? É que nas planícies homens "de muita visão", os especuladores imobiliários (\$\$\$ \$), viram novos espaços a serem ocupados por mais e mais habitações. Feito isto, estabeleceu-se um "pequeno" conflito entre as águas que insistem em inundar a planície e o povo que não é bobo mas que, sem recursos, não tem outra opção.

Faltou e falta, por esse Brasil afora, planejamento de uso do solo urbano, falta competência técnica, falta vontade política, falta a utilização da legislação farta e excessiva, só que nunca aplicada.

Impressiona a solidariedade do povo brasileiro que envia aos desabrigados água potável, roupas e víveres. Melhor assim. Dói ver crianças, ve- 
lhos e adultos desesperados banidos do local que demoraram uma vida para construir. Entretanto, toda a solidariedade é pequena diante da magnitude do desastre representado pelas irreparáveis perdas emocionais e materiais. Vidas se foram. Rolaram com as águas o abrigo, o café que se fazia na cozinha de manhã, o quarto quente que garantia o sono para a lida diária, o armário com as roupas e o álbum de fotografias das pessoas queridas. Como reconfortar os que perderam entes queridos e que viram fragmentar o espaço que permite a organização das nossas vidas: nossas casas com tudo de ponderável e imponderável que abrigam.

Luciana Maria Lopes - Professora adjunta do Instituto de Estudos Sócio-Ambientais da Universidade Federal de Goiás. 
